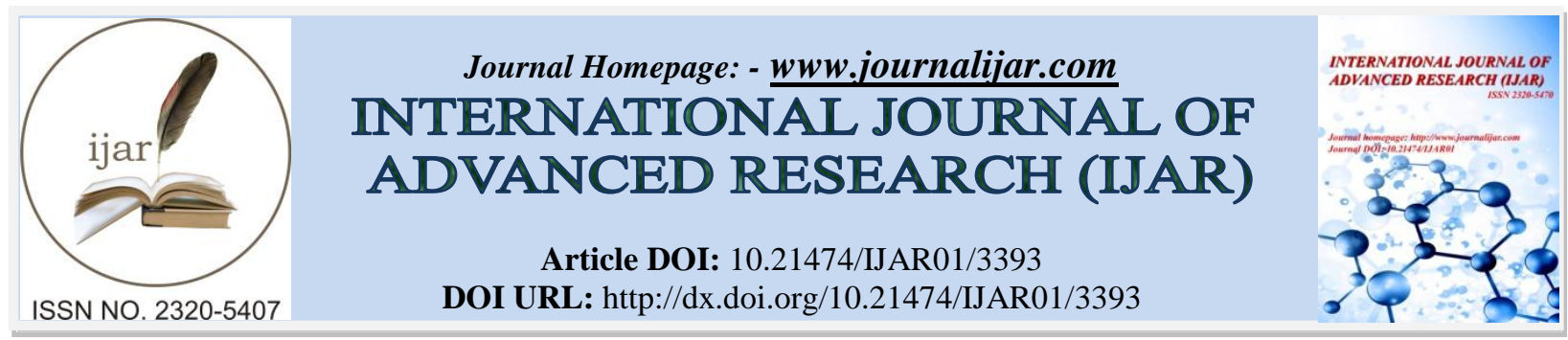

RESEARCH ARTICLE

\title{
FACTORS MILITATING AGAINST QUALITY OF ACADEMIC PERFORMANCE OF SECONDARY SCHOOL STUDENTS: A CASE STUDY OF SECONDARY SCHOOL STUDENT IN ONDO STATE, NIGERIA.
}

Dr G. O Ayenigbara and Y. H Seidu.

Science and Technical Education Department, Adekunle Ajasin University, Akungba-Akoko. Ondo State.

\section{Manuscript Info}

Manuscript History

Received: 20 December 2016

Final Accepted: 15 January 2017

Published: February 2017

Key words:-

Parents, social environment, library, laboratory, motivation, examination.

\begin{abstract}
This paper reviewed the salient factors militating against quality of academic performance of secondary school students; A case study of secondary school students in Ondo State, Nigeria. Sequel to the findings, the following conclusions were made; Adequate use of library, conducive school environment, motivation of teachers, parental factors, and effective use of equipped laboratory were the factors militating against quality of academic performance of secondary school students in Ondo State, Nigeria. Consequently, it was recommended among others that; educational budgetary allocation should be increased both at federal, state and local government levels to finance both the federal and the state public secondary schools, regular payment of teachers salary, promotion of teachers and other emoluments should be made available and the salary scale of teachers should be equal to their counterparts in other fields like medicine. In addition, more infrastructural facilities should be provided by the government and nongovernmental organization to all secondary schools and books in the library should be up-to-date.
\end{abstract}

Copy Right, IJAR, 2017,. All rights reserved.

\section{Introduction:-}

In Nigeria public discussions frequently focus on educational standards. The public's unhappiness becomes more prominent following the annual release of the West African Senior School Certificate Examination results. Student outcomes do not match the government and parental investment. All stakeholders are concerned about why the system is turning out graduates with poor results. The most important factor in the effectiveness of schools and in the quality of a child's education are the competent teacher to teach effectively. The National Policy of Education states, "No Education system can rise above the quality of teachers in the system" (FGN, 2006). Ogunsaju (2004) states that the academic standard in all Nigerian educational institutions has fallen considerably below societal expectations. Blumende (2001) corroborated this view when he reported that the decline in the quality of education cannot be ignored by anyone who is aware of the significant role of education as an instrument of societal transformation and development. There is a need to focus on teachers' adequacy and competency in respect to their pedagogical practices and strategies and mastery of the curriculum and subject content (Chall \& Popp, 1990; Stuart, 2004; Rodgers, 2001).

In Ondo state, education remains the largest industry and government contributes to ensures that funds, instructional 
materials, seminar and teaching personnel are made available for the sectors. Government has also continuously encouraged secondary education by adopting the social and demand approach towards planning the sector and by subsidizing the senior School certificate examination (SSCE) fee in the state over a long period of time. An indication of government interest in the general education in the state reflected in the 1999 budgetary estimates of the state till date.

Of course, despite the efforts being made towards ensuring that citizens have equal educational opportunities, training opportunities as well as making other training facilities readily accessible to the users so as to improve students' academic performance in both internal and external examination, it has been observed by (Ajayi, 1998; Adepoju, 2002; Owoeye, 2000), that all is not well with the system as a result of the poor performance of students recorded in public examinations in the recent years. The persistent poor performance of secondary school students in public examinations such as the senior school certificate examinations (SSCE), national examination council (NECO) in Ondo State, Nigeria in recent times has made the developments of secondary education in the state a difficult task. Parents, guardians and other stakeholders in education industry have variously commented on the performances of secondary school students particularly in English language and mathematics (Adepoju, 2002).

Researchers and stakeholders in education industry have in the recent past identified several factors as the causes of poor performance of students in public examinations. Among such factors identified are poor location of the school, incessant changes in government policies, closure of schools, which is contingent upon teachers' strike action, home-school distance, high student teacher ratio, inadequate supervision, monitoring and evaluation machinery, poor and non-conducive environment among others (Adepoju, 1995; 1998; 2002; 2003; Adeboyeje, Olaniyi Adepoju 2003).

\section{Militating factors:-}

The following factors contribute positively to students' academic performance: adequate use of library, school environment, motivation of teachers, parental factors and effective use of equipped laboratory among others.

a. Parental factors: Parental factor is one of the most important factor contributing to the academic performance of students. This factor is so important because students spent most of their life with their parents, Fan (2001) demonstrated that parents' educational aspiration for their children proved to be strongly related to students' academic growth. Research studies have found that parental educational level has a significant impact on child's learning, (Khan \& Malik, 1999). Similarly, Schneider and Lee (1990) linked the academic success of the East Asian students to the values and aspirations they share with their parents, and also to the home learning activities in which their parents involve with them. In fact, all parents have desired to do something better for their children according to their available resources. But the extent and effectiveness of parental support depends on a variety of reasons, such as, ethnicity, family income, and home environment and their awareness about the importance of education.

Research studies indicated that socio economic status is correlated strongly with parents' educational ambition for their children. Khan, Khan and Zubairi (1999) stated that "interacting with and sharing the child's activities is affected by level of parents' education and income. In the families with low socioeconomic status, majority of the illiterate parents do not have understanding of the requirements of their children's education. Some poor parents make some arrangements for helping their children in studies and to do their home assignments, while others rely on school for the education of their children, as they do not have enough resources to spend extra money on home tuitions etc. This results into poor performance and academic achievement of their children. The findings of the study conducted by Okpala, and Smith (2001) also supports the view that economic circumstances are significantly correlated with academic achievement. Research studies indicated that the nature of the parental support change at different age levels of children. Gonzalez-Pienda et al. (2002) have found that parental support is likely to decrease as children move from primary to middle and then to high school grades. Similarly, a research study by Fan, (2001) showed that children also develop sense of responsibility and perform better as they grow older. The study indicated that those students whose parents had higher expectations for their children's academic achievement performed better from the beginning of their academic career and accelerated faster in their academic progress during the transition period of middle to high grades.

The children also seek emotional support from parents when they face some academic problems at school. Educated and sensible parents always encourage their children and give proper guidance in school related matters, but illiterate and economically deprived parents may act violently and thus upset their children more. Some parents also 
helps their children to do assignment and give them less work to do at home, this gives the students the opportunity to spent more hours reading their books and conduct more research outside of what they were thought in the classroom. Research studies indicated that parental support in doing home tasks has significant effects in students' achievement, (Singh, Granville, Sandra, \& Dika, 2002; Eilam, 2001). If parents are educated, and have better understanding of how to break a problem into parts, or know more effective motivational techniques, then they can help their children more effectively. A study conducted by Voorhis (2003) demonstrated that those students who reported more parental involvement in connection with daily homework, doing their homework assignments more regularly.

b. Social environmental factors: School facilities have been observed as a potent factor to quantitative education. The importance to teaching and learning with the provision of adequate instructional facilities for education cannot be over-emphasized. According to Akande (1985), learning can occur through one's interaction with one's environment. Environment here refers to facilities that are available to facilitate students learning outcome. It includes books, audio-visual, software and hardware of educational technology; so also, size of classroom, sitting position and arrangement, availability of tables, chairs, chalkboards, shelves on which instruments for practical are arranged (Farrant, 1991 and Farombi, 1998). According to Oni (1992), facilities constitute a strategic factor in organizational functioning. This is so because they determine to a very large extent the smooth functioning of any social organization or system including education. He further stated that their availability, adequacy and relevance influence efficiency and high productivity. In his words, Farombi (1998) opined that the wealth of a nation or society could determine the quality of education in that land; emphasizing that a society that is wealthy will establish good schools with quality teachers, learning infrastructures, such students may learn with ease thus bringing about good academic achievement. In their contribution, Ajayi and Ogunyemi (1990) reiterated that when facilities are provided to meet relative needs of a school system, students will not only have access to the reference materials mentioned by the teacher, but individual students will also learn at their own paces. The net effect of this will increase overall academic performance of the entire students.

According to Hallak (1990), facilities form one of the potent factors that contribute to academic achievement in the school system. They include the school buildings, classroom, accommodation, libraries, laboratories, furniture, recreational equipment, apparatus and other instructional materials. He went further to say that their availability, relevance and adequacy contribute to academic achievement. He however, quickly added that unattractive school buildings and overcrowded classrooms among others contribute to poor academic attainment. In another development, Aliyu (1993) as cited by Johnson (1998) found that there was no significant difference between students in secondary schools with and without adequate instructional facilities. However, he submitted that instructional facilities were indispensible to academic achievement of students in English Language, Mathematics, Biology and Geography while students could perform well in other subjects without adequacy of sophisticated instructional materials. He concluded that the effect of instructional facilities on students' academic achievement is more felt in pure and social sciences.

c. Effect of libraries: Library is an essential factor in teaching-learning process. It forms one of the most important and essential educational services needed for the success of the students. The main purpose of school library is to make books available to the pupils/students, at his easy convenience, all books, periodicals and other reproduced materials which are of interest and value to him but which are not provided or assigned to him as basic or supplementary textbooks. The importance of library has been demonstrated by the government when she expressed in the National Policy on Education (NPE) that every state Ministry needs to provide funds for the establishment of libraries in all her educational institutions and to train librarians and library assistants. As a resource, it occupies a central and primary place in any school system. It supports all functions of schoolteaching and provides service and guidance to its readers. Fowowe (1988) stated that a library must be up-todate and at the same time allow access to older materials. It must be properly supported financially to fund materials and services among others. While itemizing the types of libraries, Ola (1990) thought that secondary school library in whatever form, has replaced the traditional method of 'chalk and talk' in imparting knowledge to students and that its effect on academic performance need not to be over-emphasized. He therefore, concluded that a well equipped library is a major facility which enhances good learning and achievement of high educational standard. In his words, Farombi (1998) reiterated that school libraries may not be effective if the books therein are not adequate and up-to-date as its impact may only be meaningful if the library could be opened to the students always for a considerable length of time in a school day. With all the above mentioned 
facts, it is sad to know that many schools operate without libraries (Shodimu, 1998) whereas Ogunseye (1986) had earlier noted that total absence of an organized school library would continue to spell dooms for thousands of secondary school students. This statement clearly implied that many schools operate without libraries and this situation had affected the academic performance of their students. Reporting the state of library in Lagos Secondary Schools, Shodimu (1998) submitted that the guidelines that each school should be provided with a library with 100 students seating capacity was not followed as most of the schools he sampled had seating capacity of less than 100 students.

d. Effect of motivation: Business Dictionary.com define motivation as activation of a contractor's physical and manpower resources for transfer to a construction site until the completion of the contract. It is generally assumed that motivation influences people's attitude and performance at work. Taylor and Vest (2002) asserts that pay is an important reward used in motivating the behaviour of employees. Teacher motivation is directly linked to the instructors' desire to take part in the pedagogical process and interest in sharing their knowledge with the students. It determines their involvement or non-involvement in the teaching activities. Teachers put educational philosophy and objective into the knowledge they transfer to their students. Meanwhile, they are the most important factor in a generation's education process, so it is important that they perform to the best of their abilities in the educational activity. Each country's authorities must pay attention to the factors that affect teachers' performance which has a direct effect on students' performance.

Teachers' motivation is influenced by a myriad of factors, including compensation, success in the classroom, their dedication to the profession, the training they receive, the prospect of promotion and career advancement. Compensation influences teacher education, but in many cases it is not the most or the only important factor. Teachers may be compensated through salaries, bonuses, training programs or special assistance such as shelter and transport support. If teachers are not paid, or if they are not paid on a regular basis, their motivation will be affected and they might start teaching irregularly or leave their jobs. Teachers' motivation is influenced by their working conditions too. An appropriate environment in which the teacher feels safe and healthy and has access to supportive resources and facilities will help teachers participate more in the process of teaching, management and administration. Moreover, teacher motivation is influenced by the number of hours the instructor has to work every week, the number of students in the classroom and at the same time by parents' involvement and support. Individuals are motivated by money, power or praise. As teachers can't motivate students by offering money or power, they should focus on praise. Some students are self-motivated and their actions are a result of their desire to face challenges. Teachers can praise, promote and encourage this personal trait by showing students their efforts are worthwhile and that they will benefit from them.

e. Factor of laboratory: Laboratory has been conceptualized as a room or a building specially built for teaching by demonstration of theoretical phenomenon into practical terms. Olaniyonu (1997) maintains that in secondary schools, the modern teaching of sciences will necessitate laboratories. In the words of Ogunleye (1997), one of the recurrent problems of teaching of science is that of large classes. He remarks that one of the objectives of teaching science in schools is to communicate the knowledge of science in schools and to ensure that students acquire the process skills of science. This cannot be effectively achieved unless students are exposed sufficiently to practical work and laboratory experimentation. Unfortunately, Ogunleye continued, that many secondary schools established over the years still remain without science laboratories while others have laboratories that are not sufficiently equipped. Similarly, Farombi (1998) argued the saying that "seeing is believing" as the effect of using laboratories in teaching and learning of science and other science related disciplines as students tend to understand and recall what they see than what they hear or were told, similarly Ogunniyi (1983) said that there is a general consensus among science educators that the laboratory occupies a central position in science instruction.

\section{According to Ango (1986) laboratory work:-}

$>$ Stimulate learners' interest as they are made to personally engage in useful scientific activities and experimentation;

$>$ Promotes that science is not only product or process;

$>$ Affords the learners the basic skills and scientific method of problem solving;

$>$ Knowledge obtained through laboratory work promotes long term memory, on similar objectives. 
Soyibo (1990) said laboratory helps to provide a forum wherein the learner is given the exercise to subjects, his beliefs, ideas, statements, and theoretical propositions etc to some forms of experimental test.

Soyibo and Nyong (1994) has shown that school with well-equipped laboratories have better results in the school certificate science examinations than those that are ill-equipped. Corroborating this, Gana (1997) reiterated that students instructed entirely by the laboratory methods had higher attitudes scores but lower achievement scores than students instructed entirely by the traditional lecture or textbook mode. On the same topic, Yadar (2001) opined that no course in science and mathematics can be considered as complete without including some practical work. Thus practical work forms an important feature in any science and mathematics course (UNESCO, 2008), and lastly, Olainiyonu (1997) maintains that in secondary schools, the modern teaching of science will necessitate laboratories.

\section{Conclusion and recommendations:-}

After a careful review of available literature, this paper concludes that library, school environment, motivation of teachers, parental factors, and lack of equipped laboratory were the major factors militating against quality of academic performance of secondary school students in Ondo State.

To this end, the paper recommends, among others, that:

1) The parents should take proper care of their children and bearing child without taking care off should be counted as punishable offence by government.

2) More infrastructural facilities should be provided by both the government and non-governmental organizations to fast-track the growth of educational system in the state.

3) Constructions of libraries in the schools and communities with E-learning facilities with current books should be embarked upon.

4) Regular payment of teachers salaries, promotions and other incentives should be embarked upon.

5) Standard laboratories with reagents and latest equipments should be build by both the Government and NGO across the secondary schools in the state.

6) More qualified teachers should be employed to solve the problem of shortage of teachers in various schools in the state and equipped with latest teaching techniques through in-service training.

\section{Refrences:-}

1. Adeboyeje, R. A., Olaniyi, G.B and Adepoju, T.L. (2003) Correlates of some predictor variables on students learning retention and academic achievement at the senior school certificate examinations is selected Nigerian States. A paper presented at the WAEC Monthly Seminar, Lagos (27th June).

2. Adepoju, T.L (1995) Planning of secondary education in Nigeria; A case study of Oyo State (19850-2000). Unpublished M.Ed. Dissertation, University of Ibadan.

3. Adepoju, T.L. (1998) The gap between teacher demand and supply in secondary school in Oyo State (19841994) implications for educational planning. African Journal of Educational Management $6: 51$ - 60.

4. Adepoju, T.L (2002) Locational factors as correlates of private cost and academic performance of secondary school students in Oyo State, Nigeria. Unpublished Ph.D. Thesis, University of Ibadan.

5. Adepoju, T.L (2003) Locational factors and academic performances of students in senior school certificate examinations: Oyo State as a case study. A paper presented at the WAEC monthly seminar, Lagos (28th March)

6. Ajayi, I.A (1998) Unit cost of secondary education and students academic achievement in Ondo State, Nigeria (1991-1995) unpublished Ph.D. Thesis, University of Ibadan, Ibadan.

7. Aliyu, K. (1993). Instructional Facilities and Secondary School Students Academic Performance in Bida and Lavun Local Government of Niger State. M.Ed Dissertation, University of Ilorin.

8. Ango, M. L. and Sila M.D. (1986). Teaching and Learning of Biology Practical; The Experience of some Nigerian Secondary Schools. Journal of Science Teachers Association of Nigeria, 124(1 \& 2), 33-47.

9. Blumende, R. S.(2001). Making schools effective in Nigeria. Journal of Education Research, 5(1), 65-78.

10. Chall, J.S .\& Popp, H. M. (1990). Chall - Popp Phonics: Level B (Teacher's Edition), Continental Press.

11. Fan, X. (2001). Parental Involvement and Students' Academic Achievement: A Growth Modeling Analysis. The Journal of Experimental Education, 70(1), pp. 27-61

12. Farombi, J.G. (1998). Resource Concentration, Utilization and Management as Correlates of Students' Learning outcomes: A study in School Quality in Oyo State. Unpublished Ph.D. Thesis, university of Ibadan.

13. Farrant,J. S. (1991). Principles and practice of Education (Tenth Impression Singapore Longman. Federal Republic of Nigeria. (1981). National Policy of Education. Yaba, Lagos NERC Press. 
14. Federal Republic of Nigeria (2006). National Policy on Education. NERDC, Abuja. Federal Ministry of Education (2005). Education Sector Analysis Report. Abuja.

15. Fowowe, S.O. (1988). Finding Academic Libraries In Nigeria: A survey of some Nigerian University libraries. Ilorin Journal of Education, Vol. 8, (21-16).

16. Gana, E, S. (1997). Effects of Using Visual Designed Training Models on the Learning of Mathematics at J.S.S. Unpublished Ph,D. Thesis, University of Ibadan.

17. Gonzalez-Pienda, J.A, Nunez, J.C., Gonzalez-Pumariega, S., Alvarez, L., Roces, C. \& Garcia, M. (2002). A Structural Equation Model of Parental Involvement, Motivational and Aptitudinal Characteristics, and Academic Achievement. The Journal of Experimental Education, 70(3), pp. 257-287

18. Hallak, J. (1990). Investing in the future: Setting educational priorities in the developing world. Paris: UNESCO- 11EP.

19. http://www.businessdictionary.com/definition/mobilization.html\#ixzz3iL5jsmOm

20. Johnson, A. B. (1998). School Mapping and Resource Supply as Correlates of students Academic Achievement in Kwara State Secondary Schools, Unpublished Ph.D Thesis, University of Ibadan.

21. Khan, R.M. \& Malik, K. (1999). Effectiveness of Parents' involvement in reading, child's overt behavior at home, mothers' educational level on children's reading comprehension. Journal of Elementary Education. Institution of Education and Research, Punjab University, Lahore.

22. Khan, R.M.; Khan, M. A \&Zubairi, N. (1999). Parental Involvement and reading Attainment: A Study of 4th Grade Pakistani Children, Journal Pendidikan,20, pp. 83-94, Fakulti Pedidikan University, Malaya,

23. Ogunniyi, M.B. (1983). Analysis of Laboratory Activities in Selected Nigerian Secondary Schools. European Journal and Science Education, Vol. 5, (2).

24. Ogunsaju, S. (2004). A Guide to School Effectiveness in Nigeria. Ibadan. Laville Publications.

25. Ogunseye, F. (1986). The Learning Resources: Factor in Education and its implication of mass Failure Conference paper Presented at Ibadan.

26. Okpala, C.O., Okpala, A.O, \& Smith, F.E. (2001). Parental Involvement, Instructional Expenditures, Family Socioeconomic Attributes, and Student Achievement. The Journal of Educational Research, 95( 2), pp. 110115

27. Ola, J.R. (1990). The Place of School Library in the New 6-3.3-4 Educational System. Teachers Journal Ondo State ANCOPSS (2nd Ed), Ibadan, Evans Brothers Nigeria Publishers.

28. Oni, J.O. (1992). Resource and Resource Utilisation as Correlates of School Academic Performance. Unpublished Ph.D Thesis, University of Ibadan

29. Owoeye, J.S. (2000) The effect of interaction of location, facilities and class size on academic achievement of secondary school students in Ekiti State Nigeria. Unpublished Ph.D. Thesis, University of Ibadan, Ibadan.

30. Schneider, B. \& Lee, Y. (1990). A Model for Academic Success: The School and Home Environment of East Asian Students. Anthropology \& Education Quarterly, 21( 4), pp. 358-377

31. Shodimu, G.O. (1998). Resource Availability, Utilization and Productivity in Public and Private Secondary Schools in Lagos State; A Ph.D seminar paper, University of Lagos.

32. Singh, K., Granville, M., \& Dika, S. (2002). Mathematics and Science Achievement: Effects of Motivation, Interest, and Academic Engagement, The Journal of Educational Research, 95 (6) pp. 323-332:

33. Soyibo, K and Nyong, G.O.E. (1984). An Analysis of the School Certificate Biology Result of Old and New Secondary Schools in Cross Rivers State 1978 - 1982. Nigerian Educational Forum 7(2), 245 - 250.

34. Taylor and Vest (2002) Taylor, G. S. and Vest, M. J. (1992) "Pay Comparisons and Satisfaction among Public Sector Employees", Public Personnel Management, Vol. 21, pp 445-54.

35. UNESCO. (2008). Challenges of implementing free day secondary education in Kenya. Experiences from district. Nairobi: UNESCO.

36. Van Voorhis, F.L. (2003). Interactive Homework in Middle School: Effects on Family Involvement and Science Achievement. The Journal of Educational Research, 96 (6),pp. 323-338

37. Yadar. K. (2001). Teaching of Life Sciences. New Delhi, Anmol Publication. Ltd. India 